\title{
Governance and Shareholder Response to Chief Risk Officer Appointments
}

\author{
Manu Gupta, Puneet Prakash and Nanda Rangan \\ 301, W. Main Street, School of Business, Virginia Commonwealth University, Snead Hall, Richmond, \\ VA 23284, U.S. \\ E-mails: mgupta2@vcu.edu; pprakash@vcu.edu; nkrangan@vcu.edu
}

This study examines the recent, significant growth in the appointments of Chief Risk Officers (CROs), the role of a CRO, and whether such appointments benefit shareholders. We find that the market is more likely to react positively to a CRO appointment for a firm with weak corporate governance. In particular, the lower the proportion of outside directors the greater is the likelihood of a positive market reaction to CRO appointments, suggesting that CRO appointments are associated with better future governance by firms' shareholders. Finally, firms with higher tax and product risk also experience increases in stock prices when they appoint CROs.

The Geneva Papers (2012) 37, 108-124. doi:10.1057/gpp.2011.30;

published online 23 November 2011

Keywords: risk management; ERM; governance; Chief Risk Officer

\section{Introduction}

As the ripple effects of the financial crisis of 2008 continue, it is clear that a regulatory compliance approach to risk management under the Sarbanes-Oxley Act of 2002 was inadequate $^{1}$ and can still result in ex-post failures. Consequently, there is an increased focus on a holistic approach to manage risk espoused in Enterprise Risk Management (ERM). The Dodd-Frank Act of 2010 highlights the informational aspects associated with instruments used to manage risk and calls for increased transparency of risk exposures across financial system. Recent studies, like Simkins and Ramirez ${ }^{1}$ and the Senior Supervisors Group, ${ }^{2}$ emphasise on the deficiencies of corporate governance and its effective linkage to ERM that ultimately were factors that led to the crisis of 2008.

Corporate governance increases firm value when it mitigates information asymmetry between financial markets and firms, and lowers cost of agency conflicts among firm's stakeholders. In this paper, we examine the role of ERM and its relation to firm value from the perspective that one of its primary goal is to monitor risk taking by incumbent managers. To the extent that risk managers independently ensure that their firm takes risks within the confines of established guidelines and not other risks, ${ }^{3}$ they add value to the firm as delegated monitors of risk taking. However, in presence

\footnotetext{
${ }^{1}$ Simkins and Ramirez (2008).

${ }^{2}$ SSG (2009).

${ }^{3}$ Stulz (2008).
} 
of "unknown unknowns", 4 risk managers have to forego their quantitative models and resort to subjective assessments of risk. In such situations, Stulz ${ }^{3}$ warns, there is real danger that risk management becomes embroiled in intra-firm politics resulting in risk managers adding to the agency conflicts and destroying shareholder value. Tufano ${ }^{5}$ also describes a situation in which risk management can potentially destroy value. In the example considered in Tufano's study, managers can place cash flow hedges to meet their investment needs and avoid market monitoring associated with raising external capital. Risk management that allows managers to bypass this monitoring mechanism actually exacerbates the shareholder-manager agency conflict and hence destroys value.

So how do shareholders value the monitoring role of the ERM function where monitoring is normally associated with governance? To answer this question we employ the standard two-step event methodology. ${ }^{6}$ In the first step, we measure stockholder response to the appointment of a Chief Risk Officer (CRO), a signal that is often utilised as a proxy for ERM. ${ }^{7}$ In the second, we examine the likelihood of shareholders responding positively or negatively to CRO appointments depending upon the financial characteristics and governance structure of the firms prior to the announcement of a CRO hire.

To the extent that share prices capture expectations about governance quality in the future, if shareholders perceive the appointment as strengthening of governance, they are more likely to react positively, and vice-versa. Thus, in a cross-section of firms, we expect those firms to experience a positive market reaction to $\mathrm{CRO}$ appointments where there are weak governance structures, as shareholders of such firms are more likely to view the appointment as strengthening the governance of risk taking.

The governance characteristics we include in this study are the percentage of outside directors on the board, the proportion of shares owned by managers of the firm, and block holder ownership. Rosenstein and $\mathrm{Wyatt}^{8}$ associate percentage of outside directors to increase in firm value. Wagner ${ }^{9}$ presents a model in which board independence and competence are inextricably linked to its effectiveness, hence positively to firm value. When managers hold a larger percentage of the shares, information asymmetry between the firm and outsiders increases, ${ }^{10}$ suggesting that greater insider ownership is associated with weaker governance. Finally, if large block holders are present, they are expected to monitor the firm better and to that extent improve shareholder value. ${ }^{11}$ However, if the blockholders are also insiders, they may be able to extract rents at the expense of the minority shareholders, given they are better informed. Hence, presence of large blockholders can be positively or negatively related to the quality of governance.

\footnotetext{
${ }^{4}$ See section 3.3 on page 929 in Jorion (2009).

5 Tufano (1998).

${ }^{6}$ Acharya (1993).

${ }^{7}$ See Liebenberg and Hoyt (2003); Pagach and Warr (2011).

${ }^{8}$ Rosenstein and Wyatt (1990).

${ }^{9}$ Wagner (2011).

${ }^{10}$ Han and Suk (1998); Brown et al. (2007).

${ }^{11}$ Shleifer and Vishny (1986).
} 
110

Using a sample of CRO appointment announcements during years 1999-2009, we find that the average stock price reaction to the announcement is not statistically different from zero. However, we find that there is a large variation in the stock price reaction, and about half of the sample announcements elicit a positive reaction. We split the sample into two, positive and negative, announcement returns, to study if governance characteristics determine the difference in stock price reaction. We find that positive stock price reaction is more likely to occur in firms that suffer from weak governance.

In particular, we find that the lower the proportion of outside directors, the greater is the likelihood of a positive market reaction to the appointment of a CRO. Both insider ownership and blockholder ownership have no significant effect on the likelihood of how shareholders react. The relationship between board independence and likelihood of positive market reaction is robust to control of insider ownership.

We control for firm financial characteristics as suggested by theoretical rationales for ERM, namely, expected bankruptcy costs, tax costs, costs of external capital, product and asset risks, and find that firms facing higher volatility of taxes paid (a proxy for risk of tax cost) and product risk have a higher probability of eliciting a positive market reaction when they hire a CRO. Finally, we find no evidence that market reaction to firm announcement is driven by its industry. Absence of industryspecific effects on the market reaction suggests that shareholders' response to the appointment of a CRO is not industry-dependent once we account for governance.

The median firm in the top quartile of board independence in our sample experiences a negative stock price reaction of nine basis points (bps), but the median firm in bottom quartile experiences a positive $31 \mathrm{bps}$ return. Similarly, the return for the median firm in the lowest (highest) quartile of product risk is $-17(+9)$ bps. Finally, the median firm in the top (bottom) quartile of tax risk elicits a +16 (only +2 ) bps return when a CRO is hired. These findings show that shareholders of firms with varying governance quality, tax, and product risk respond asymmetrically to CRO appointments.

All results presented above are robust to different event windows, alternative measures of abnormal returns, and event study methodologies. We conclude that our evidence is consistent with the hypothesis that shareholders are more likely to react positively when firms suffering from weak corporate governance hire a CRO.

Our study contributes to the existing literature on ERM in a number of ways. First, we offer evidence on the valuation effects of CRO appointments to the corporate governance stream of ERM literature. ${ }^{12}$ We show that firms' governance practices affect shareholder perception of CRO appointments. We also provide evidence that from a shareholder's perspective, a CRO's role extends beyond financial aspects of ERM to include monitoring of risk taking, a role traditionally associated with corporate governance mechanism. While prior studies find that a firm's industry characteristics contributes to adoption of ERM, we report that in our sample we do not find evidence that industry effects drive shareholder reactions to ERM once we account for the firm's governance. Finally, we provide additional evidence for

${ }^{12}$ Beasley et al. (2005); Simkins and Ramirez (2008); Stulz (2008). 
some of the theoretical rationales for ERM affecting firm value as suggested in the extant literature.

The rest of the paper is organised as follows. In the next section, we review the extant literature and develop our hypothesis. In the section after that we describe the data, methodology. In the subsequent section we discuss the results and their implications. We offer conclusions in the last section.

\section{Literature review and hypothesis development}

In a perfect world of Modigliani and Miller, ${ }^{13}$ ERM is irrelevant since atomistic investors can undertake home-made risk management on their own. However, in the presence of market frictions, ERM may affect shareholder value. Smith and Stulz ${ }^{14}$ model the value-enhancing effect of risk management arising from the progressive tax schedules and lower expected bankruptcy costs. Froot et al. ${ }^{15}$ posit that risk management is value-enhancing when external capital is more expensive than internal capital. In their model, hedging that reduces the volatility of cash flows and is valueenhancing. Similarly, Smith and Stulz ${ }^{14}$ argue that risk-neutral corporations hedge risks because managers are risk averse. Tufano ${ }^{16}$ finds empirical evidence in favour of the managerial risk aversion hypothesis of Smith and Stulz. Despite new developments and interest in ERM, lack of good and comprehensive data on ERM has constrained academic research, especially in providing insights into the firms' valuation of risk management policies and practice.

Early studies had taken one of two approaches to address the lack of good and comprehensive data. Under the first approach, studies either narrow down the analysis to a single industry or seek to provide insights via case studies of firms. Tufano ${ }^{16}$ finds that gold corporations hedge gold price risk despite being risk neutral as their managers are risk averse. Mackay and Moeller ${ }^{17}$ reports that the practice of risk management adds value to the firms in the oil refining industry to the tune of 2 per cent.

The second approach in prior papers that focus on the value of risk management revolves around the analysis of risk management products that firms employ in their operations, primarily derivatives. Graham and Rogers ${ }^{18}$ find firms use interest rate derivatives to increase debt capacity and interest tax deductions. A comprehensive review of this literature in Smithson and Simkins ${ }^{19}$ concludes that risk management enhances firm value, even though evidence is limited.

More recent studies employ the presence of a CRO as a proxy for ERM practice within a firm. ${ }^{7}$ These studies explore the determinants of CRO hires, and find leverage (bankruptcy risk), volatility of cash flows, institutional ownership, and size

\footnotetext{
${ }^{13}$ Modigliani and Miller (1958).

${ }^{14}$ Smith and Stulz (1985).

${ }^{15}$ Froot et al. (1993).

16 Tufano (1996).

${ }^{17}$ Mackay and Moeller (2007).

${ }^{18}$ Graham and Rogers (2002).

${ }^{19}$ Smithson and Simkins (2005).
} 
112

influence CRO hiring. Beasley et al. ${ }^{20}$ examine shareholder reaction to CRO appointment and find the mean cumulative abnormal return (CAR) surrounding the hiring of a CRO is insignificantly different from zero. However, they find that high liquidity elicits a negative market reaction, while large size evokes a positive one.

The lack of a significant stock price reaction on average in prior studies to events relating to ERM and CRO appointments, although unexpected, given the growth in risk management tools and its practice in corporate firms, may be a result of two opposite effects that confound the impact of these events on valuation. Theoretical rationales outlined earlier in this section argue that risk management is value enhancing. Hence, the hiring of a CRO for the ERM function within a firm can be viewed positively by shareholders.

An opposing view posits that risk management is viewed unfavourably by shareholders since it signals private rent extraction by managers. In Tufano's ${ }^{5}$ model, managers place cash flow hedges to meet their investment needs and avoid market monitoring associated with raising external capital. In such cases managers have the potential to extract private benefits from investments of the firm though not from its free cash flows. Shareholders' inability to prevent this "siphoning" of funds ex-ante reduces the net inflows to them. Hence, shareholders do not wish to manage risks which enable the manager to continue to draw private benefits. Risk management then exacerbates the shareholder-manager agency conflict and hence destroys value. This view suggests the practice of ERM signals higher future agency costs, and hence, shareholders will react negatively to the hiring of a CRO.

Given opposing views on the effect of risk management on stock price, the question whether the positive or negative effect dominates stock valuation upon appointment of a CRO, therefore, is an empirical issue. The opposing views, however, do indicate that the value of the CRO may differ across firms.

We draw upon the corporate governance literature to assess if the firms' governance structure affects shareholders' reaction to CRO appointments. Rosenstein and Wyatt ${ }^{8}$ document a positive abnormal market reaction to an outside director appointment to the board. Gupta and Fields ${ }^{21}$ conclude that outside director resignations appear to send negative signals to market participants. Overall, the dominant view is that corporate governance impacts the value of the firm.

Recent studies have explored links between corporate governance and ERM, in particular the risk monitoring function. Beasley et $a .^{22}$ find that firms with ERM programmes are more likely to have a CRO; greater independence on the board of directors; a larger size; or belong to banking, education, or insurance industries. Jorion $^{23}$ finds that the institutions that lost the most during the crisis of 2008 were hierarchical in nature and the top management often ignored warning signals given by risk managers. Stulz $z^{3}$ establishes a direct link between risk control and incentives by hypothesising that risk monitoring and control will be more effective in firms where

\footnotetext{
${ }^{20}$ Beasley et al. (2008).

${ }^{21}$ Gupta and Fields (2009).

22 Beasley et al. (2005).

23 Jorion (2009).
} 
employee incentives are aligned with the risk-taking objectives of the firm. Dionne and $\mathrm{Triki}^{24}$ find the requirements on the audit committee size and independence, of the type imposed by NYSE rules, benefit shareholders. On the other hand, Desender and Lafuente $^{25}$ report firms with independent boards and concentrated ownership show the highest level of ERM practices in the U.S. These studies examine the link between risk management, governance, and firm value indirectly, but not around any event such as hiring of a CRO. If governance and ERM are linked, then CRO appointment events become relevant for empirical examination even though the effects may differ across firms.

Consistent with the argument in Dionne and Triki, ${ }^{24}$ addition of a CRO who reports to the board of directors can further enhance the board's ability to encourage financial hedging and thus the appointment of a CRO can be considered valueenhancing for the firm. Thus, value enhancing rationales for ERM whether related to governance or other financial characteristics would suggest a positive stock price reaction to the news of hiring of a CRO.

On the contrary, if the ERM function itself is an indicator of exacerbation of agency issues as suggested by Tufano, ${ }^{5}$ then appointments of CROs will be associated with negative stock price reaction. It is likely to be even more negative for firms with weak corporate governance structure, since the appointment will be perceived as another signal by shareholders that insiders intend to continue to extract private benefits.

Consequently, our main hypotheses are that the stock price reaction to the announcement of the hiring of a CRO will be different across firms with diverse corporate governance structures, and that firms having weaker governance are more likely to experience positive market reactions to a CRO hiring.

\section{Data, methodology, and variables}

\section{Data and methodology}

We search the PR Newswire on Lexis-Nexis database for the hiring announcements for senior executives carrying out the risk management function. In particular, we search for "Chief Risk Officer", "Risk Manager", "Risk (Management) Director", and "Enterprise Risk Officer" with and without prefix "Chief" in the headlines. ${ }^{26}$ We focus only on publicly traded firms in the U.S. given their financial data is readily available. Beasley et $a l^{20}$ state that hiring announcements for risk managers became more prevalent in the late 1990s, and Pagach and Warr ${ }^{27}$ report that their data is clustered in the period 1999-2002, which is why we start our search from 1999, and end it in $2009 .^{28}$

${ }^{24}$ Dionne and Triki (2005).

${ }^{25}$ Desender and Lafuente (2009).

${ }^{26}$ We also searched for "Vice-President", "Head" in combination with the word "Risk" and "Risk Management".

27 Pagach and Warr (2011).

${ }^{28}$ Both, Pagach and Warr (2011) and Beasley et al. (2008) start their search in 1992 in an attempt to capture the first time appointment of a senior level risk officer, signalling the start of an Enterprise Risk Management programme. However, they do not find a significant abnormal stock price reaction around 
114

We are able to identify 102 announcements over a 11-year period. Our sample size is similar and comparable to samples sizes of 120 announcements over a 12-year period in Beasley et al., ${ }^{20}$ and 138 in Pagach and Warr $^{27}$ over a 14-year period. We then search for confounding events and remove 22 observations that had earnings or dividend announcements, corporate fraud revelations, CEO turnover, or mergers and acquisitions announcements in a five-day window surrounding the announcement of a risk officer. ${ }^{29}$ Usable returns that were not available on CRSP for seven observations were excluded. This resulted in a final sample of 73 observations. We employ the standard two-step event study methodology to compute CARs at the time of announcement of the hiring of a senior risk in the first step, and then subsequently analysing the CARs in the cross section of firms in the second.

Financial data for the fiscal year prior to the announcement date is obtained from the COMPUSTAT database. The corporate governance data comes from firms' last proxy statements filed before the CRO appointment announcement date.

To study the market reaction to CRO appointments, in the first step we employ the standard market model ${ }^{30}$ given by:

$$
R_{i t}=\alpha_{i}+\beta_{i} R_{m t}+\varepsilon_{i t}
$$

The abnormal return for security $i$ on day $t\left(A_{i t}\right)$ is:

$$
A_{i t}=R_{i t}-\left(\widehat{\alpha}_{i}+\hat{\beta}_{i} R_{m t}\right)
$$

The CAR for security $i$, when the event window starts at $T_{1}$ and ends at $T_{2}$ is computed as

$$
C A R_{i}=\sum_{t=T_{1}}^{T_{2}} A_{i t}
$$

And the mean CARs for $N$ securities is calculated as follows,

$$
\text { Mean } C A R_{T_{1}, T_{2}}=\frac{1}{N} \sum_{i=1}^{N} \sum_{t=T_{1}}^{T_{2}} A_{i t}
$$

where $R_{m}$ is the CRSP value weighted index. We employ an estimation window of 255 days ending 30 days prior to the event date and require firms to have at least 30 days of returns data during the estimation period. Although we report CARs

the announcement dates. Since we do not plan to study first time appointments anyway, we start our sample in 1999.

${ }^{29}$ Pagach and Warr (2011) and Beasley et al. (2008) do not indicate if they remove confounding events from their sample.

${ }^{30}$ For robustness of announcement returns, we also examine the market adjusted returns and find similar results. Market adjusted returns on day $t$ are computed by subtracting the return on the market index from firm $i$ 's return on day $t$, i.e., $A_{i t}=R_{i t}-R_{m t}$. 
for four different event windows, we employ the 2-day window $(-1,0)$ for multivariate analysis.

To test whether the mean CAR in Eq. (4) is significantly different from zero, we employ a parametric test based on unit normal distribution called Patell Z. ${ }^{31}$ However, when abnormal returns are skewed and/or fat tailed, parametric tests reject too often when testing for positive returns, and too seldom when testing for negative returns. In such cases, a non parametric test based on the limiting binomial distribution (unit normal) called generalised sign Z (GS) is used. ${ }^{32}$ The null hypothesis for the GS test is the probability of a positive CAR in the event window equals the percentage of positive CARs observed in the estimation period. We report both parametric and non-parametric tests.

After computing the abnormal returns, we analyse the variation in CARs in the cross section of firms in the second step. In particular, we divide the firms into positive and negative CAR firms and apply a multivariate logistic regression analysis, along the lines undertaken in Zhang. ${ }^{33}$ The logistic regression (we drop the subscript $i$ ) takes the form:

$$
\ln \left(\frac{\pi}{1-\pi}\right)=f(\text { Corporate Governance, Firm ERM determinants })
$$

where $\pi$ refers to likelihood of a positive CAR for the firm surrounding the announcements.

\section{Variables}

We employ three variables that relate to corporate governance. All three are obtained from the last proxy statement filed with the SEC prior to the announcement date of the CRO hiring. Good corporate governance is directed towards reduction of agency costs within the firm, and this responsibility rests with the board of directors of the firm. The board of directors in their monitoring role within the corporate governance system is viewed as the primary means by which shareholders exercise control over management. ${ }^{8}$ Therefore, to evaluate the effect of corporate governance, the first variable we employ is the per cent of outside directors, which captures board independence. Next, we use per cent of shares held by block-holders (block shares), that is by owners with 5 per cent or more of the firm's stock, as large shareholders also perform monitoring function to reduce agency costs. ${ }^{11}$ Finally, we employ management shares that reflect the percentage of shares held by management or insider ownership. Larger insider ownership is known to affect corporate value negatively. ${ }^{34}$

\footnotetext{
${ }^{31}$ See Patell (1976).

${ }^{32}$ The test statistic generalized sign $Z(G S)$ equals $\left(\left|p_{o b s}-p_{H}\right|\right) /\left(\sqrt{p_{H}\left(1-p_{H}\right) / N}\right)$, where $p_{H}$ is the hypothesized fraction of positive returns (mostly set equal to the fraction of positive returns in the estimation period), and $p_{o b s}$ is the percentage of positive returns in the event period, and $N$ is the number of firms in the sample.

33 Zhang (1997).

${ }^{34}$ Rosenstein and Wyatt (1997).
} 
116

We control for variables that provide theoretical rationales for ERM and/or have been employed in the prior studies on ERM. We control for the size effect on ERM using natural log of market value of assets (MVA) computed as the sum of market value of common equity and book value of liabilities. We include the standard deviation of the ratio of income tax paid to MVA, to control for the volatility of convex tax costs. ${ }^{14}$ Expected bankruptcy costs are an often cited reason for ERM, and Liebenberg and Hoyt ${ }^{35}$ find that leverage is an important factor for a firm's decision to undertake ERM. We thus include both liquidity ratio (measured as the ratio of sum of cash and equivalents to MVA) and leverage (measured as the ratio of sum of long-term debt and debt in current liabilities to market value of common equity). Beasley et al. ${ }^{20}$ and Pagach and Warr ${ }^{27}$ hypothesise that a firm's growth options will positively impact the decision to manage risk. As external capital is more expensive than internal capital, firms with growth options will benefit by managing risk and minimising the chance of raising external capital. We capture growth options using the natural log of ratio of market to book value of assets. Finally, both product risk and asset risk are known to affect bankruptcy risk. ${ }^{36}$ Lee and Stowe $^{37}$ present a model in which trade credit captures product risk in equilibrium. We capture the effect of a firm's credit policy on the CRO hiring decision using the volatility of the accounts receivable ratio where accounts receivables ratio is the percentage of accounts receivable to sales. Asset risk is captured by the variability in return on assets (ROA). We use data over eight quarters ending in the last quarter prior to the CRO appointment announcement to compute all volatility measures and average ratios.

\section{Empirical results and discussion}

CRO appointments in our sample, as described in Table 1, are clustered around three industries, with the rest of the sectors comprising the fourth group. Nine of these CRO appointments are from insurance companies (SIC codes 63 and 64), 43 from banks and other financial services (SIC codes 60, 61 and 62), and 10 from utility firms (SIC code 49). The remaining six industry codes (SIC codes 20, 32, 50, 52, 73, and 87) account for 11 data points in the sample. Years 2006 and 2007 (just preceding the 2008 banking crises) account for a significant number (23 out of 73) of CRO appointment announcements. Similarly, years 2001 and 2002 provide the least number of data points (five in all), which correspond to the year of the Enron scandal, and the Sarbanes-Oxley Act, respectively. The drop in sample size is similar to that of Pagach and Warr $^{27}$ in the wake of the Enron scandal, as the focus of firms shifted to compliance with audit regulation laid down in Sarbanes-Oxley.

The industry composition is consistent with prior studies and survey data finding that highly regulated industries, such as financial services and insurance, are among the early adopters of ERM due to growing regulatory calls for ERM. ${ }^{22}$ S\&P started assessing ERM for insurance companies in 2004 before extending it to all firms in

\footnotetext{
${ }^{35}$ Liebenberg and Hoyt (2003).

${ }^{36}$ See Baranoff et al. (1999); Baranoff and Sager (2003).

${ }^{37}$ Lee and Stowe (1993).
} 
Table 1 Distribution of CRO appointment announcement over time and industry

\begin{tabular}{|c|c|c|c|c|c|}
\hline \multirow{2}{*}{ Year } & \multirow[t]{2}{*}{ Total } & \multicolumn{4}{|c|}{ CRO announcement by industry } \\
\hline & & Utility & Banks and other financial firms & Insurance & Other \\
\hline 2000 & 6 & 1 & 2 & 1 & \\
\hline 2001 & 1 & 1 & & & \\
\hline 2002 & 4 & 3 & 1 & & \\
\hline 2003 & 7 & & 5 & 2 & \\
\hline 2004 & 8 & 1 & 5 & & 2 \\
\hline 2005 & 8 & 1 & 6 & & 1 \\
\hline 2006 & 13 & 1 & 8 & 3 & 1 \\
\hline 2007 & 10 & 1 & 7 & 1 & 1 \\
\hline 2008 & 8 & 1 & 5 & 1 & 1 \\
\hline 2009 & 8 & & 4 & 1 & 3 \\
\hline Total & 73 & 10 & 43 & 9 & 11 \\
\hline
\end{tabular}

Table 2 Summary statistics for variables used in the study

\begin{tabular}{lcccccc}
\hline Variable & $N$ & Mean & Median & Std & Minimum & Maximum \\
\hline Market value of assets & 73 & $102,100.29$ & $20,874.58$ & $282,016.53$ & 224.94 & $1,629,817.7$ \\
Pct of outside directors & 67 & 0.7574 & 0.8125 & 0.1894 & 0 & 0.9333 \\
Management shares & 66 & 0.0782 & 0.0291 & 0.1050 & 0.0020 & 0.552 \\
Block shares & 63 & 0.2583 & 0.2150 & 0.2136 & 0 & 0.762 \\
Income tax ratio & 72 & 0.0016 & 0.0012 & 0.0020 & -0.0077 & 0.008 \\
Liquidity ratio & 72 & 0.0651 & 0.0393 & 0.0813 & 0.0065 & 0.5246 \\
Accounts receivables ratio & 73 & 21.5082 & 16.2573 & 20.1704 & 0 & 86.736 \\
Leverage & 71 & 1.6920 & 0.7301 & 2.6787 & 0.0023 & 14.5309 \\
Natural log of market-to-book & 72 & 0.2823 & 0.1877 & 0.2920 & 0.0383 & 1.8156 \\
Return on assets & 72 & 0.0028 & 0.0029 & 0.0044 & -0.0164 & 0.0129 \\
\hline
\end{tabular}

Note: Market value of assets are in millions US\$.

2008. Stulz ${ }^{3}$ argues that financial firms are more exposed to risk since their asset values are more susceptible to market fluctuations than manufacturing firms. We therefore, find that the sample is largely confined to the utility, banking and financial services and the insurance industry.

Table 2 provides firm characteristics that we use in our multivariate analysis. The median size of the firm in the sample is US\$20.8 billion. The mean (median) percentage of outside directors on the board equals 75.7 per cent (81.25 per cent) for the sample firms. The management owns about 7.8 per cent $(2.91$ per cent) and block holders own 25.8 per cent ( 21.50 per cent) of the sample firms' outstanding shares on average (at the median). Firms in our sample pay 0.16 per cent in corporate income taxes as a percentage of their total assets. The accounts receivable to sales ratio varies from a minimum of $0-86.8$ per cent with an average of 21.5 per cent, showing some firms undertake a majority of sale on credit terms. 
Table 3 Cumulative abnormal returns (CARs)

Market model returns

\begin{tabular}{lccccccc}
\hline Days & $N$ & $\begin{array}{c}\text { Mean cumulative } \\
\text { abnormal return (\%) }\end{array}$ & $\begin{array}{c}\text { Positive: } \\
\text { negative }\end{array}$ & Patell $Z$ & $\begin{array}{c}\text { Generalized } \\
\text { sign } Z\end{array}$ & $\begin{array}{c}\text { Minimum } \\
\text { CAR }(\%)\end{array}$ & $\begin{array}{c}\text { Maximum } \\
\text { CAR }(\%)\end{array}$ \\
\hline$(-1,+1)$ & 73 & 0.05 & $35: 38$ & 0.110 & -0.198 & -10.52 & 10.41 \\
$(-1,0)$ & 73 & 0.34 & $33: 40$ & 0.634 & -0.666 & -5.96 & 12.82 \\
$(-2,+2)$ & 73 & 0.11 & $35: 38$ & 0.177 & -0.198 & -8.39 & 17.38 \\
$(-2,0)$ & 73 & 0.50 & $38: 35$ & 0.957 & 0.504 & -6.52 & 15.89 \\
\hline
\end{tabular}

Mean cumulative abnormal returns are not significantly different from zero.

Table 3 reports the event study results using the market model. ${ }^{38}$ We use four different event windows $(-1,+1),(-1,0),(-2,+2)$ and $(-2,0)$. We find that the average stock price reaction for all four event windows is positive, although insignificantly different from zero. The most commonly utilised window for event studies is $(-1,0)$ under the assumption that the market anticipates these events. Over this two-day window, we find mean CAR of +0.34 per cent. The minimum two-day CAR is -10.52 per cent while the maximum is +10.41 per cent. The CARs for all windows display a wide range covering both positive and negative values.

The analysis of the proportion of positive-to-negative reactions shows that close to half of the sample experience positive stock price reaction. Since the other half experiences a negative reaction, the overall reaction is insignificantly different from zero. The insignificance of the market reaction, though not surprising, is consistent with the notion that the effect of CRO appointments varies across firms and hence impact on firm valuation is highly dispersed. Our results are similar to the findings reported in Beasley et al. ${ }^{20}$

\section{Multivariate results}

We study firm characteristics that are likely to lead to a positive stock price reaction from the shareholders. We categorise these characteristics into two groups, corporate governance and financial characteristics that have been linked to ERM in prior studies. Three corporate governance measures form variables of our interest: (i) the percentage of outside directors (proxy for board independence), (ii) insider ownership, and (iii) block holder ownership. The financial characteristics variables we include are size, market-to-book ratio, leverage and liquidity, asset risk, product risk, and the risk of tax cost.

In Table 4, we run four different specifications (SPEC 1 - SPEC 4) of the logistic regression model of previously shown Eq. (5), to estimate the likelihood of a positive market reaction to an appointment of a CRO. Since number of predictors to observations is low and we wish to control the variance inflation, each model includes one corporate governance variable, except SPEC 4, which combines percentage of outside directors and management shareholdings in one regression. Further, because

\footnotetext{
${ }^{38}$ We find similar results using market adjusted returns.
} 


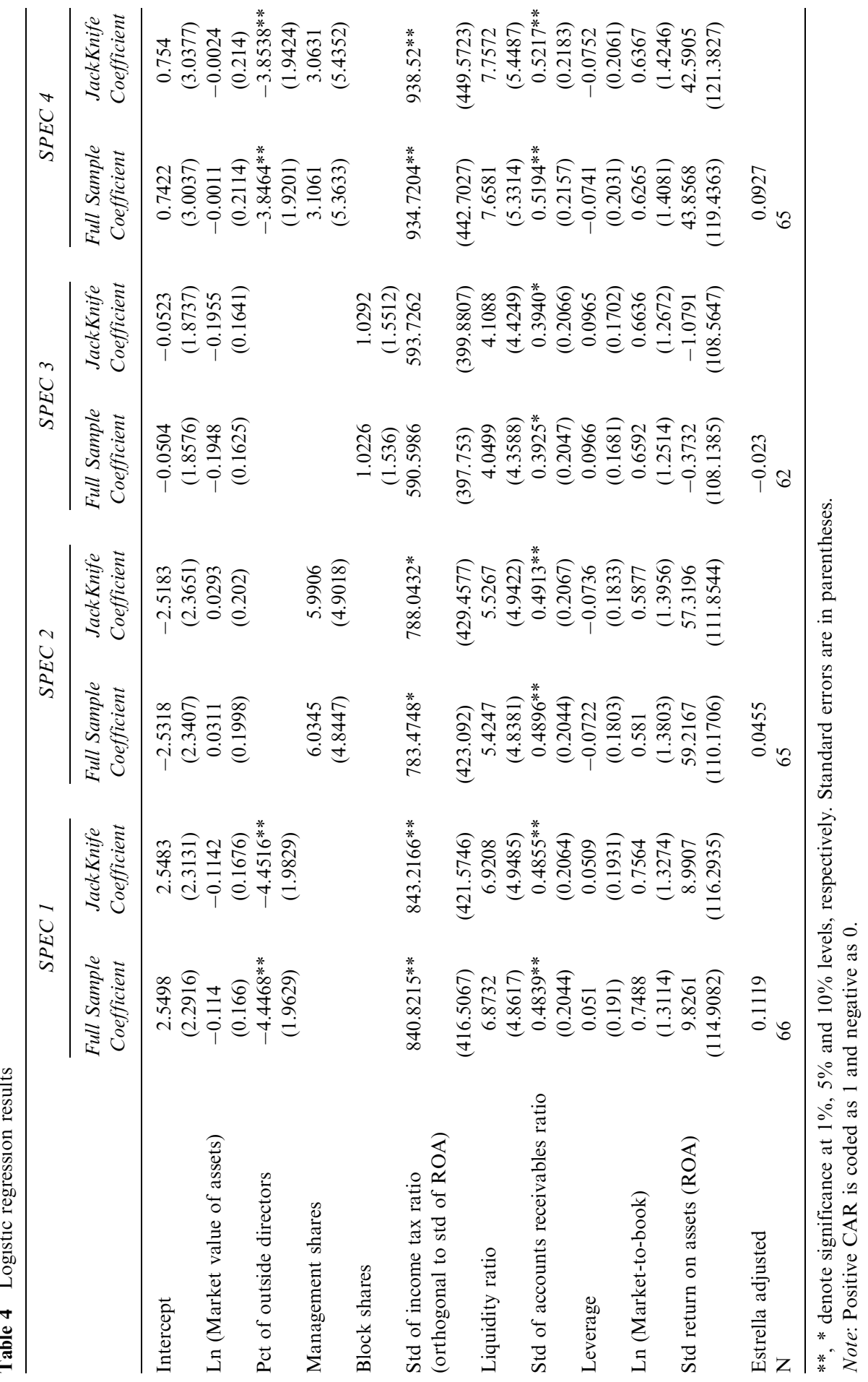


120

of the small sample size, we also carry out the jackknife procedure and present the mean and standard error of our jackknife estimates alongside the full sample estimates for each specification.

In general, if shareholders perceive that the appointment of a CRO will improve the firm's corporate governance then such firms (with weaker corporate governance mechanisms) are more likely to experience a positive market reaction than others. Instead, if an appointment of a CRO signals continuation and/or exacerbation of agency problems then firms with weaker governance are less likely to experience a positive stock price reaction. We test for this hypothesis by examining the relation between the strength of corporate governance mechanisms and likelihood of a positive market reaction to appointment of a CRO.

We find that the likelihood of a positive stock price reaction is negatively related with board independence measured by pct of outside directors (SPEC 1, coefficient $=-4.45$, $\mathrm{p}$-value $<5$ per cent). This implies that firms with less independent boards are more likely to experience a positive stock price reaction, suggesting a governance role of a CRO. The findings are consistent with Desender and Lafuente $^{25}$ who report that there is a positive association between board independence and ERM activity.

Out of the firm's determinants of ERM activity, we find that two variables contribute significantly to a higher likelihood of a positive stock price reaction. The volatility of tax costs measured by std of income tax ratio $^{39}$ (coefficient $=840.82$, p-value $<5$ per cent) is positively associated with the chances of a positive reaction. The finding is consistent with the tax rationale for ERM put forth in Smith and Stulz. ${ }^{14}$ Similarly, product risk of firms proxied by std of accounts receivables ratio (coefficient $=0.48, \mathrm{p}$-value $<5$ per cent) is positively related to the likelihood of a positive market reaction. Other financial determinants of ERM activity are not significantly related to the likelihood of positive vs. negative reaction.

In SPEC 2 we examine whether insider ownership (management shares) is related to a likelihood of a positive reaction to a CRO appointment and find the relation to be statistically insignificant. Again, of all the financial determinants of ERM activity, the product risk increases the likelihood of a positive reaction (coefficient $=0.48$, p-value $<5$ per cent) and so does the volatility of taxes (coefficient $=783.48, p$-value $<5$ per cent).

SPEC 3 examines the effect of the percentage of shares held by block holders (block shares) on the likelihood of a positive reaction. Again, we find that block holder ownership is unrelated to the likelihood of positive market reaction. Of other variables, only the product risk characteristic shows up significantly (coefficient $=0.39$, p-value $<1$ per cent) in this specification.

Finally, in specification (4), we employ board independence and inside ownership to test the robustness of the relation between board independence and the likelihood of a

\footnotetext{
${ }^{39}$ Since the volatility of income tax ratio is highly correlated to volatility of return on assets (ROA) ratio, we run an OLS of volatility of income tax ratio against volatility of ROA ratio and use the residuals in the logit regression. Thus the values of volatility of income tax ratio are net of (orthogonal to) volatility of ROA.
} 
positive market reaction. We find that board independence (coefficient $=-3.85$, p-value $<5$ per cent) is significantly related to the likelihood of a positive reaction, and dominates the percentage of shares held by management. Both the volatility of the tax ratio (coefficient $=934.72, \mathrm{p}$-value $<5$ per cent) and product risk characteristics (coefficient $=0.52$, p-value $<5$ per cent) continue to be significant amongst the financial variables that determine ERM.

Given that board independence, volatility of taxes and product risk play a significant role in determining how shareholders react, we examine if membership in a top vs. bottom quartile group of each parameter can make a difference between a positive or a negative reaction. We find that the median firm in the top quartile of board independence experiences a negative stock price reaction of 9 basis points (bps), but the median firm in bottom quartile experiences a positive 31 bps return. Similarly, the return for the median firm in the lowest quartile of product risk is $-17 \mathrm{bps}$, but the return for the median firm in the highest quartile of product risk $+9 \mathrm{bps}$. However, the median firm in each (lowest or highest) quartile formed on the basis of volatility of taxes (net of asset risk) experience positive reactions. The median firm in the top quartile of tax risk elicits a +16 bps reaction, while the median firm in the bottom quartile only +2 bps when a CRO is hired.

Overall, we find that stockholders are more likely to react positively when the firm has a weaker governance structure in the form of less independent board of directors. Shareholders are also more likely to react positively when the firm faces higher volatility of taxes or the firm has riskier products.

To verify that the logit models presented in Table 4 have better predictability than a coin toss, we conduct a prediction analysis of the four specifications (SPEC 1-4). The small size of the sample does not permit a hold-out sample, so we undertake a jackknife procedure. In this procedure we hold out one firm at a time and predict the class it will belong to positive or negative CAR using regression estimates obtained from the remaining firms in the sample. We then check the predicted class against the firm's actual class to check if the number of correct predictions made by the model is better than a random chance. Table 5 presents the results of this analysis.

For each SPEC 1-4, Panel A presents classification based on full sample estimates and Panel $B$ the classification based on jackknife estimates. We find that SPEC 1 identifies approximately 63 per cent of the positive or negative reactions correctly. The full sample estimates of SPEC 4 identify 67 per cent of the stock price reactions (positive or negative) correctly, while the jackknife estimates identify the class of 64 per cent of the firm correctly. Given that classes are formed based on stock returns which are, by and large, assumed to follow a random walk in the academic literature, the results of Table 5 demonstrate that the logit model of Eq. (5) has better predictability than attributable to random chance. The finding strengthens our conclusion that when firms having weak governance structures appoint a CRO they are likely to receive a positive bounce in their stock prices.

\section{Conclusion}

Given the significant growth in the CRO appointments in recent years, we examine the shareholder reaction to such appointments. Recent studies have used the CRO 
Table 5 Predicted group based on full sample and jackknife estimates

\begin{tabular}{|c|c|c|c|c|c|c|c|}
\hline & \multicolumn{3}{|c|}{ SPEC 1} & & \multicolumn{3}{|c|}{ SPEC 2} \\
\hline & \multicolumn{3}{|c|}{ Predicted } & & \multicolumn{3}{|c|}{ Predicted } \\
\hline & $\begin{array}{c}C A R \text { is } \\
\quad+\text { ve }\end{array}$ & $\begin{array}{c}C A R \text { is } \\
-v e\end{array}$ & $\begin{array}{c}\% \\
\text { Correct }\end{array}$ & & $\begin{array}{l}\text { CAR is } \\
+ \text { ve }\end{array}$ & $\begin{array}{c}C A R \text { is } \\
-v e\end{array}$ & $\begin{array}{c}\% \\
\text { Correct }\end{array}$ \\
\hline \multicolumn{4}{|c|}{ Panel A: Full sample estimates } & \multicolumn{4}{|c|}{ Panel A: Full sample estimates } \\
\hline Actual CAR is + ve & 15 & 9 & 62.50 & Actual CAR is + ve & 16 & 10 & 61.54 \\
\hline \multirow[t]{2}{*}{ Actual CAR is - ve } & 15 & 27 & 64.29 & Actual CAR is - ve & 13 & 26 & 66.67 \\
\hline & & Total & 63.60 & & & Total & 64.60 \\
\hline \multicolumn{4}{|c|}{ Panel B: Jackknife estimates } & \multicolumn{2}{|c|}{ Panel B: Jackknife estimates } & & \\
\hline Actual CAR is + ve & 16 & 10 & 61.53 & Actual CAR is + ve & 14 & 9 & 60.87 \\
\hline \multirow[t]{5}{*}{ Actual CAR is - ve } & 14 & 26 & 65.00 & Actual CAR is - ve & 15 & 27 & 64.29 \\
\hline & & Total & 63.40 & & & Total & 61.41 \\
\hline & \multicolumn{3}{|c|}{ SPEC 3} & & \multicolumn{3}{|c|}{$S P E C 4$} \\
\hline & \multicolumn{3}{|c|}{ Predicted } & & \multicolumn{3}{|c|}{ Predicted } \\
\hline & $\begin{array}{c}C A R \text { is } \\
+v e\end{array}$ & $\begin{array}{c}C A R \text { is } \\
-v e\end{array}$ & $\begin{array}{c}\% \\
\text { Correct }\end{array}$ & & $\begin{array}{l}\text { CAR is } \\
+ \text { ve }\end{array}$ & $\begin{array}{c}C A R \text { is } \\
-v e\end{array}$ & $\begin{array}{c}\% \\
\text { Correct }\end{array}$ \\
\hline \multicolumn{4}{|c|}{ Panel A: Full sample estimates } & \multicolumn{4}{|c|}{ Panel A: Full sample estimates } \\
\hline Actual CAR is + ve & 12 & 9 & 57.14 & Actual CAR is + ve & 15 & 7 & 68.18 \\
\hline \multirow[t]{2}{*}{ Actual CAR is -ve } & 15 & 26 & 63.41 & Actual CAR is -ve & 14 & 29 & 67.44 \\
\hline & & Total & 61.30 & & & Total & 67.70 \\
\hline \multicolumn{4}{|c|}{ Panel B: Jackknife estimates } & \multicolumn{4}{|c|}{ Panel B: Jackknife estimates } \\
\hline Actual CAR is + ve & 12 & 15 & 44.44 & Actual CAR is + ve & 15 & 9 & 62.50 \\
\hline \multirow[t]{2}{*}{ Actual CAR is -ve } & 9 & 26 & 74.29 & Actual CAR is - ve & 14 & 27 & 65.85 \\
\hline & & Total & 61.13 & & & Total & 64.13 \\
\hline
\end{tabular}

Note: SPEC $1-4$ are given in Table 4.

position as a proxy for a firm's ERM programme, and hence we explore the role of a CRO in an organisation, from the perspective of a risk monitor of the firm. In line with prior studies, not surprisingly, we find that the CARs surrounding the announcement of CROs, though positive, are not significantly different from zero. A more detailed analysis of firms with positive vs. those with negative reaction reveals that likelihood of a positive reaction is related to the firm's governance mechanism. In particular, we find that the market reaction is more likely to be positive when a firm has a weaker governance structure in the form of less independent board of directors, suggesting appointment of a CRO may be viewed as strengthening governance. As far as the traditional rationales for ERM based on a firm's financial characteristics are concerned, we find that shareholders are more likely to react positively when the firm faces uncertainty in taxes and has higher product risk. Absence of industryspecific effects in shareholder reaction in our sample shows the response of shareholders to a signal of ERM (appointment of a CRO) is not industry-dependent once we account for governance. 
This study raises a question if CROs are substitutes or complements to the traditional corporate governance mechanism, since their role as risk monitors are valued by the shareholders. However, due to the nature and scope of this study, we leave this question for future research.

\section{Acknowledgements}

We thank Etti Baranoff and Betty Simkins for inputs on the initial draft of the paper.

\section{References}

Acharya, S. (1993) 'Value of latent information: Alternative event study methods', Journal of Finance 48(1): $363-385$.

Baranoff, E.G. and Sager, T.W. (2003) 'The relations among organizational and distribution forms and capital and asset risk structures in the life insurance industry', Journal of Risk and Insurance 70(3): 375-400.

Baranoff, E.G., Sager, T.W. and Witt, R.C. (1999) 'Industry segmentation and predictor motifs for solvency analysis of the life/health insurance industry', Journal of Risk and Insurance 66(1): 99-123.

Beasley, M.S., Clune, R. and Hermanson, D.R. (2005) 'Enterprise risk management: An empirical analysis of factors associated with the extent of implementation', Journal of Accounting and Public Policy 24(6): 521-531.

Beasley, M.S., Pagach, D. and Warr, R. (2008) 'Information conveyed in hiring announcements of senior executives overseeing enterprise-wide risk management processes', Journal of Accounting, Auditing \& Finance 23: 311-332.

Brown, J.R., Liang, N. and Weisbenner, S. (2007) 'Executive financial incentives and payout policy: Firm responses to the 2003 dividend tax cut', Journal of Finance 62(4): 1935-1965.

Desender, K. and Lafuente, E. (2009) The influence of board composition, audit fees and ownership concentration on enterprise risk management, Working Paper, Centre for Entrepreneurship \& Business Research (CEBR), Bucharest, Romania.

Dionne, G. and Triki, T. (2005) Risk management and corporate governance: The importance of independence and financial knowledge for the board and the audit committee, Working Paper, HEC, Montreal.

Froot, K.A., Scharfstein, D.S. and Stein, J.C. (1993) 'Risk management: Coordinating corporate investment and financing policies', Journal of Finance 48(5): 1629-1658.

Graham, J.R. and Rogers, D.A. (2002) 'Do firms hedge in response to tax incentives?' Journal of Finance 57(2): 815-839.

Gupta, M. and Fields, L.P. (2009) 'Board independence and corporate governance: Evidence from director resignations', Journal of Business Finance and Accounting 36(1-2): 161-184.

Han, K.C. and Suk, D.Y. (1998) 'Insider ownership and signals: Evidence from stock split announcement effects', The Financial Review 33(2): 1-18.

Jorion, P. (2009) 'Risk management lessons from the credit crisis', European Financial Management 15(5): 923-933.

Lee, Y.W. and Stowe, J.D. (1993) 'Product risk, asymmetric information, and trade credit', Journal of Financial and Quantitative Analysis 28(2): 285-300.

Liebenberg, A.P. and Hoyt, R.E. (2003) 'The determinants of enterprise risk management: Evidence from the appointment of Chief Risk Officers', Risk Management and Insurance Review 6(1): 37-52.

Mackay, P. and Moeller, S.B. (2007) 'The value of corporate risk management', Journal of Finance 62(3): 1379-1419.

Modigliani, F. and Miller, M. (1958) 'The cost of capital, corporation finance and the theory of investment', American Economic Review 48(3): 261-297.

Pagach, D. and Warr, R. (2011) 'The characteristics of firms that hire Chief Risk Officers', Journal of Risk and Insurance 78(1): 185-211. 
Patell, J. (1976) 'Corporate forecasts of earnings per share and stock price behavior: Empirical tests', Journal of Accounting Research 14(2): 246-276.

Rosenstein, S. and Wyatt, J.G. (1990) 'Outside directors, board independence and shareholder wealth', Journal of Financial Economics 26(2): 175-191.

Rosenstein, S. and Wyatt, J.G. (1997) 'Inside directors, board effectiveness and shareholder wealth', Journal of Financial Economics 44(2): 229-250.

Senior Supervisors Group (2009) 'Risk management lessons from the global banking crisis of 2008' http:// www.sec.gov/news/press/2009/report102109.pdf.

Shleifer, A. and Vishny, R.W. (1986) 'Large shareholders and corporate control', Journal of Political Economy 94(3): 461-489.

Simkins, B. and Ramirez, S.A. (2008) 'Enterprise-wide risk management and corporate governance', Loyola University Chicago Law Journal 39: 571-594.

Smith, C.W. and Stulz, R.M. (1985) 'The determinants of firms' hedging policies', Journal of Financial and Quantitative Analysis 20(4): 391-405.

Smithson, C. and Simkins, B.J. (2005) 'Does risk management add value? A survey of the evidence', Journal of Applied Corporate Finance 17(3): 8-17.

Stulz, R. (2008) 'Risk management failures: What are they and when do they happen?' Journal of Applied Corporate Finance 20(4): 39-48.

Tufano, P. (1996) 'Who manages risk? An empirical examination of risk management practices in the gold mining industry', Journal of Finance 51(4): 1097-1137.

Tufano, P. (1998) 'Agency costs of corporate risk management', Financial Management 27(1): 67-77.

Wagner, A. (2011) 'Board independence and competence', Journal of Financial Intermediation 20(1): 71-93.

Zhang, H. (1997) 'Repeated acquirers in FDIC assisted acquisitions', Journal of Banking and Finance 21(10): 1419-1430.

\section{About the Authors}

Manu Gupta is Assistant Professor of Finance at Virginia Commonwealth University. His research interests include Corporate Governance, Executive Compensation, Earnings Manipulation, and Regulatory Institutions. He has published in Journal of Law and Economics, Journal of Banking and Finance, and Journal of Business Finance and Accounting. He has been quoted in Financial Times, London, The Washington Post, and St. Louis Post Dispatch. He has received several awards for his contributions to research and teaching.

Puneet Prakash is Assistant Professor in the Finance, Insurance and Real Estate Department. His research interest lies broadly in the area of Risk Management, and he teaches risk, insurance, and corporate finance courses. He has won competitive research grants from the Dean of School of Business at VCU, and presented research papers at both national and international conferences.

Nanda Rangan is the Chair of Finance Insurance and Real Estate Department. He has published over 50 articles in leading finance and economics journals such as Journal of Finance, Journal of Financial Economics, Review of Financial Studies, Journal of Banking and Finance, Financial Management, Financial Review, Review of Economics and Statistics, and Managerial Decision Economics. He is a recipient of several awards for excellence in teaching and research, and has served on the editorial boards of three journals. 